\title{
Fewer Early Surgical Site Infections After Hip \\ Fracture and Lessons Learned From the Safe Hands Project: A Five-Year Longitudinal Study of 3,553 Patients
}

\author{
Annette Erichsen ( $\nabla$ annette.erichsen.andersson@gu.se ) \\ Health and Care sciences, University of Gothenburg https://orcid.org/0000-0002-4785-8544 \\ Brigid M Gillespie \\ Griffith University Menzies Health Institute Queensland

\section{Magnus Karlsson} \\ Sahlgrenska University Hospital: Sahlgrenska universitetssjukhuset

\section{Henrik Malchau} \\ University of Gothenburg Institute of Clinical Sciences: Goteborgs universitet Institutionen for kliniska \\ vetenskaper
}

\section{Bengt Nellgård}

University of Gothenburg Institute of Clinical Sciences: Goteborgs universitet Institutionen for kliniska vetenskaper

\section{Ewa Wikström}

University of Gothenburg School of Business Economics and Law: Goteborgs universitet Handelshogskolan

\section{Cecilia Rogmark}

Lunds University Faculty of Medicine: Lunds universitet Medicinska fakulteten

Jontan Tillander

University of Gothenburg Institute of Clinical Sciences: Goteborgs universitet Institutionen for kliniska vetenskaper

\section{Research}

Keywords: Surgical site infections, Hip fracture, Hip surgery, infection prevention, Implementation research, Knowledge translation

Posted Date: December 29th, 2021

DOI: https://doi.org/10.21203/rs.3.rs-1113332/v1 
License: (c) (i) This work is licensed under a Creative Commons Attribution 4.0 International License. Read Full License 


\section{Abstract}

Background: Surgical site infection after acute hip fracture surgery is a devastating complication associated with increased suffering and mortality. The aim of the study was to investigate early SSI, sepsis, pneumonia and urinary tract infections over five years, before and after the implementation of the Safe Hands project.

Methods: This was a single-centre observational study with a five-year longitudinal design, investigating the effects of an infection-prevention intervention targeting the clinical care pathway of individuals with acute hip fracture. Statistical analyses were based on routinely collected patient outcome data comprising 3,553 patients. The study conforms to the criteria of the Strengthening the Reporting of Observational Studies in Epidemiology (STROBE).

Results: The incidence of early SSIs decreased from $2.5 \%$ in years $1-2$ to $1.1 \%$ in years $4-5$. Similar results were observed for sepsis (2.7\% to $1.3 \%)$ and urinary tract infections $(14.2 \%$ to $4.2 \%)$. The multivariable regression shows that, for every observed year, the odds of early SSIs decreased. Male gender, procedure time, sepsis and preoperative skin damage increased the odds significantly.

Conclusions Our preventive bundle, based on partnership between researchers, managers and clinicians and a strong commitment to change from the involved professions, appear to be effective in reducing the frequency of potentially devastating SSIs and other HAls after hip fractures surgery. The use of external and internal facilitators was crucial to enable individual and organisational learning and overcoming barriers to improvements.

Trial registration: Clinical Trials.gov ID: NCT02983136 Registered 6 December 2016 - Retrospectively registered.

\section{Background}

Surgical site infection (SSI) after acute hip fracture surgery is a devastating complication associated with increased suffering and mortality $(1,2)$. The reported infection rates vary between $1.7 \%$ and $10 \%$ in relation to diagnostic criteria, fixation method and follow-up (3-5). Suffering a hip fracture is associated with an increased risk of death in particular the first year after surgery $(6,7)$ The consequences in terms of hospital costs and resources are substantial in terms of prolonged hospital length of stay (HLOS), reoperations and extra medication (8). Patients with hip fractures are generally older, frail and suffering comorbidities such as chronic obstructive pulmonary disease, diabetes and dementia. The abovementioned conditions are established patient-related risk factors for SSI, but most are inherently less modifiable than in elective procedures $(3,6,9,10)$.

Modifiable independent risk factors such as operating time are well described, while the use of drainage is unsettled (5). In previous studies, we have found unjustified differences in intra-operative care between different surgical methods (11). Preventive measures were not used to the same extent in hip fracture 
surgery compared with primary hip or knee arthroplasty (12). A general lack of hand hygiene and aseptic techniques in the OR, especially during anaesthetic care, was identified (12-14), together with the fact that organisational structures, conflicting goals and power issues often worked as barriers to change. In cases of success, supportive relationships between the managers from different professions and organisational levels were essential, along with a strong sense of ownership and control over the implementation process (15). Given the prevalence of hip fractures, the patients' vulnerability and their need for surgery to regain functional independence, there was a strong commitment among hospital management and researchers to improve the quality of care. To address the identified contextual problems, the Safe Hands project was initiated (ClinicalTrials.gov ID: NCT02983136) with the aim of testing and evaluating an implementation programme to increase awareness of the problem of hospitalacquired infections (HAl) and increase the use of preventive measures including hand hygiene, with the emphasis on the vulnerability of patients with hip fractures. The programme had an iterative, flexible approach, allowing for the co-creation of solutions and adaptations to the specific contextual factors. The implementation process for components in the programme and the links to theory have previously been published $(16,17)$. The initial project was expanded to involve the entire hip fracture care pathway, targeting catheter-related urinary tract infections, the risk of bladder distention and deficits in hand hygiene and aseptic techniques. The aim of the present study was to investigate early SSI, sepsis, pneumonia and urinary tract infections (UTI) over five years, before and after the implementation of the Safe Hands project.

\section{Methods}

\section{Design and setting}

This single-centre observational study used a five-year longitudinal design. The study was conducted at the largest orthopaedic university hospital in the Nordic countries. Statistical analyses were based on routinely collected patient outcome data. This study conforms to the criteria of the Strengthening the Reporting of Observational Studies in Epidemiology (STROBE) (18).

As standard, all the included patients received a single dose of preoperative parenteral antibiotic prophylaxis, $2 \mathrm{~g}$ of cloxacillin, unless a type 1 penicillin allergy was known or suspected. Before draping, the incision site was prepped with an alcoholic chlorhexidine solution $(5 \mathrm{mg} / \mathrm{ml})$. Double gloves were used and the outer gloves were changed if indicated. All scrub nurses were registered nurses (RNs) with a specialisation in perioperative care (one-year master's degree). Fixation with gentamicin-loaded bone cement was used in all hemiarthroplasties.

\section{Data source}

All patients recorded in the hospital's quality registry from year 1 (May 2015) to year 5 (Mars 2020) were eligible for inclusion, (Year 1: baseline, year 2-3: intervention phase and year: 4-5 follow up). After Mars 2020, Covid-19 hit the hospital with full force, consequently not eligible for inclusion in the present study. The inclusion criteria were: i) age > 65 years, ii) surgically treated hip fracture and iii) perioperative care at 
an orthogeriatric ward in our hospital. Exclusion criteria: i) HLOS < 2 days, ii) pathological fracture, iii) excision arthroplasty and iv) re-fracture or a contralateral hip fracture., Variables and definitions are presented in Box 1. The hospital's quality register contains prospectively collected in-hospital data related to orthogeriatric hip fractures.

\section{The bundle intervention and changes in standard practices}

Ongoing interventions in complex hospitals settings can yield both positive synergies and competing interests and conflicting goals within the organisation. This paper considers this complexity by reporting all the relevant method and organisational changes occurring during the five-year study period. The components of the Safe Hands project and other changes in hospital standard practices are presented in Table 1.

\section{Data collection}

Prospectively collected register data over five years were used to analyse early SSIs and other infectious outcomes. In addition, other organisational changes unrelated to the Safe Hands project were recorded. The data files were scrutinised by a research nurse and missing data were corrected in the register whenever possible. Outliers were verified against source data (i.e. patient records). The data files were cleaned according to the inclusion and exclusion criteria, outlined in Table 2 for included and excluded patients.

\section{Statistical methods}

Primary outcome: early SSI, secondary outcomes: sepsis, pneumonia and UTI. For categorical variables, $\mathrm{n}$ (\%) is reported and, for continuous variables, the mean (SD)/median (min;max). For comparisons between ordered groups, the Mantel-Haenszel chi square test was used for dichotomous and ordered categorical variables, while the Jonckheere-Terpstra test was used for continuous variables. Univariable and multivariable logistic regression were used for predictors of SSIs, unadjusted and adjusted for age and gender. A multivariable logistic regression analysis was performed. The variables were included together and selected, based on the results of the univariable analysis, and, for clinical relevance, years 15, gender, procedure time, sepsis and skin damage. "UTC more than once" was not included, because the association with SSI is multifactorial. It is probable that an IUC is the result of an SSI rather than a cause.

P-values, odds ratios (OR) with a 95\% confidence interval and area under the ROC curve are based on original values and not on stratified groups. All significance tests were two-sided and conducted at the $5 \%$ significance level. Data were analysed with the SPSS statistical package version 25 (IBM Corp. Armonk, NY, USA) and SAS Version 9.4, SAS Institute, Cary, NC, USA.

\section{Results}

The results are based on an analysis of data comprising 3,553 patients. Patient and clinical characteristics are presented in Table 3. There were few changes in the case mix over the years, although 
there were more patients with cognitive impairments in years 4-5 compared with years 1-2. HLOS decreased by three days from years 1-2 to years 4-5.

\section{Surgical site infections}

The frequency of early SSIs decreased from $2.5 \%$ in years $1-2$ to $1.1 \%$ in years $4-5$ (Table 4 ). The overall frequency SSI in hemiarthroplasty was $2.7 \%$, while it was $1.5 \%$ for internal fixation.

In the univariable analyses (adjusted for age and gender), an earlier year in the study period, gender, sepsis, severe pressure ulcer (Norton stage 4), skin damage, sepsis and IUC more than once significantly increased the odds of developing an SSI (Table 5).

Patients with SSIs had twice as long a mean HLOS of 22.5 days (95\% Cl 18.0-27.1) compared with 11.8 days without SSIs (95\% Cl 9.1-12.49) p <.0001. Patients with early SSIs also suffered from more other infections than those without: UTI $13.3 \%$ vs $8.3 \%$, sepsis $11.9 \%$ vs $4.7 \%$ and pneumonia $10.5 \%$ vs $7.0 \%$.

The multivariable regression model results suggest that (OR: $95 \% \mathrm{Cl}$ ); year (0.77: 0.64-0.94), male gender (1.71:1.03-2.82), procedure time (the OR displays changes per 1 minute) (1.01: 1.0-1.02), sepsis (4.58: 1.98-10.59) and skin damage (1.67: 1.01-2.75) contributed significantly to the model, the area under the ROC curve, with $(95 \% \mathrm{Cl})=(0.69: 0.63-0.79)$.

\section{Hospital-acquired infections}

Significant reductions in HAls other than SSIs were also seen for UTI (14.2-4.2\%) and sepsis (2.7-1.3\%). No significant differences were observed for pneumonia (Table 4).

Of 77 patients with sepsis in this cohort, $20 \%$ were diagnosed on admission and $80 \%$ were hospital associated. Fifty-nine \% were of unknown origin, $14 \%$ and $5 \%$ secondary to a urinary tract infection and pneumonia respectively. The mean HLOS for patients without sepsis was 12 days (95\% Cl 11.6-12.1), while it was 23 days for those with hospital-associated sepsis (95\% Cl 15.6-31.1).

\section{Discussion}

During the study period, we observed that in-hospital SSIs and other nosocomial infections following treatment and care for hip fractures can be significantly reduced by using the bundle approach based on the Safe Hands project. The initial early SSI rate in our cohort lies in the mid-range of previously reported rates (19) and the rate after the bundle interventions was in the lower range (20). Rates of pneumonia and unspecified infection increased slightly in the fifth study year and this is probably attributable to Covid-19. For every year, the odds of an early SSI decreased, despite that there were significantly more patients with cognitive impairment and nursing home residents in the last two study years, indicating greater frailty in the cohort (21). In line with the literature, male gender, prolonged procedure time and more than one urinary catheterisation increased the odds of early SSIs $(2,17,19)$. In contrast, age, diabetes and an ASA score did not predict SSI in our cohort. The identification of discrete modifiable risk 
factors is clinically desirable to ensure optimal intervention. The strong association between sepsis and SSI was not surprising (22); it stresses the importance of handling all medical devices, such as venous and urinary catheters, with strict adherence to hand hygiene guidelines and aseptic techniques (23). $S$. aureus bacteremia, albeit to a lesser extent if hospital acquired, increases the risk of bacterial seeding to a previously inserted orthopaedic implant or another biomedical device, thereby compounding morbidity (24-26). There are studies from several centres including our hospital that report decreased mortality and hospital re-admission in key infections, including $S$. aureus bacteremia, following early Infectious disease consultations $(27,28)$. To this end, $S$. aureus alarms and the increased availability of bedside ID consultations were introduced in the second quarter of the first study year and in the first quarter of the third study year, respectively. Skin lesions on admission and severe pressure ulcers constituted a very high risk of SSI. The latter is a modifiable risk factor that shows the importance of a team effort preventing complications in surgery; by including RNs and emphasising the importance of optimal nursing care, pressure ulcers can be avoided. However there is a need for high-quality trials, establishing the optimal repositioning frequency in this patient group (29).

\section{Strengths and limitations}

As this is a single-centre observational study, there are caveats when it comes to the interpretation of these results. In addition, other changes in hospital standard practices, many of which were developed in relation to the growing organisational focus on this patient group, have probably impacted the results of the Safe Hands interventions. What we can see is a probable reciprocal effect where the different changes reinforce the results in terms of patient outcome. However, we have tried transparently to report all the changes that have occurred during the five years included here to minimise the risk of overstating the influence the Safe Hands project has had on clinical practice. The study also has its strengths, such as the large study cohort of 3,553 patients. To avoid imputation errors, the registered data have been validated against patient records. The local quality register started in 2015 and the number of patients included in it has fluctuated over the years. Fewer patients were included in the first years of the register. The estimated completeness in the first year was approximately $60 \%$, based on a median value of included patients in years 2 to 5 . No systematic errors that can explain the lack of imputation in the first year of the register have been found.

Using only routinely collected data to analyse outcome has its limitations. As a result, other important prognostic and confounding factors, such as blood transfusion, body weight and smoking, have not been controlled for in the statistical analysis.

Bundle approaches have inherent strengths and limitations. Previous bundle interventions have proven useful in improving the quality of care and reducing SSIs in HF patients $(6,20)$ and other serious HAls, such as blood-stream infections (30) and ventilator-associated pneumonia (31). Others have criticised bundle approaches and challenged their usefulness, as it is difficult or even impossible to tease out the parts of the bundle that have contributed to the desired change and the extent. We argue that this criticism is less important than the potential benefits of bundles. Moreover, it might be useful to move 
away from linear thinking where every single part can be measured and understood, to acknowledge the complexity of change and view the transformation process from a holistic perspective where the whole is greater than the simple sum of parts.

\section{Lessons learned}

At the start of the Safe Hands project, we aimed to create sustained improvements in the treatment and care of older individuals with hip fracture, with special emphasis on infection prevention. The results of the present study indicate sustained improvements and, moreover, the incidence of early SSIs, UTIs and bloodstream infections continued to decrease even after the interventions were implemented in year three and the research team left the site. It is common for most interventions to show an effect in the short run, but the challenge has been to create sustained improvements after the intervention(32), a challenge we were aware of when deciding on the implementation strategy. We see some explanations of our promising results and sustained effect. Implementation theories and frameworks has highlighted how contextual factors can both promote and hinder the uptake of evidence-based care (33-36). For this reason, the results of our study cannot be understood without acknowledging contextual mechanisms such as leadership engagement, resources, an organisational safety culture and commitment to change. To add another layer of complexity, the Safe Hands implementation programme was aimed at surgeons, RNs, specialised RNs and nurse assistants, leaders (formal and informal) and managers. To handle this complexity, the programme was based on facilitating mechanisms for contextual negotiation and collective action; 1) Building a strong partnership between researchers, management and clinicians based on mutual respect, 2) External and internal facilitation as a role and a process that focused on enabling and supporting individual and organisational learning $(37,38)$. We found that the choice of facilitators was critical and needed to be adapted to match the context. To be perceived as trustworthy, these facilitators needed to have an in-depth understanding of the medical context and infection prevention. The internal facilitators were introduced step by step and represented all the professional categories. When the external facilitator left the site, the internal facilitators remained and were able to function as local championns (16). In this way, the improvements and learning in clinical practice could continue and may be one contributory factor in terms of the sustained and reduced infection rates. 3) Dialogue and cocreation, to facilitate organisational learning. Isaacs' (39) and Schein's (40-42) work has demonstrated the significance of creating space for dialogue. From their work, we used interprofessional dialogue to learn more about one's own and co-workers' ways of thinking about infection prevention and to inquire collectively about how available knowledge could best be transformed into co-creating and testing new ways of working together to reduce the risks of infection after surgery. As a result, the work aimed to create a cultural change instead of modifying behaviours. For this to occur, we found, in line with previous studies $(41,43)$ (p. 305), that the creation of psychological safety, mediated by respectful dialogue, was imperative to facilitate transformation.

Initially, very few people in the organisation appeared to acknowledge the magnitude of the problem with HAls. Competing interests and other daily problems to resolve may have shadowed the infection issue. By using local quality data as a basis for dialogue with the management and clinicians lead to increasing 
awareness and a shared sense of urgency in relation to the problem. Most managers and clinicians developed the motivation to engage in the transformative work, even if not everyone was motivated to make changes. To sum up, the Safe Hands project changed the way risks, safety and infection prevention were perceived in relation to hip fracture patients (16) and significantly improved patient outcomes.

\section{Conclusions}

Our preventive bundle, based on partnership between researchers, managers and clinicians and a strong commitment to change from the involved professions, appear to be effective in reducing the frequency of potentially devastating SSIs and other HAls after hip fractures. The use of external and internal facilitators was crucial to enable individual and organisational learning and overcoming barriers to improvements

\section{Declarations}

\section{Ethical approval and consent to participate}

Ethical approval was obtained from the Regional Ethics Review Board in Gothenburg, Sweden, (reference number 166-15 and amendment 327-17). Patients received written information about the quality register, with information on who to contact about their register data if they did not want their data to be used for research purposes.

\section{Consent to publication}

Not applicable

\section{Availability of data and materials}

Data are available in response to reasonable requests.

\section{Competing interests}

No competing interests declared

\section{Funding}

This work was supported by Landstingens Ömsesidiga Försäkringsbolag (http://lof.se) and the University of Gothenburg Centre for Person-centred Care (GPCC) Sweden. The GPCC is funded by the Swedish Government's grant for Strategic Research Areas (Care Sciences) and the University of Gothenburg, Sweden. The funding bodies played no role in the design of the study, data collection, analysis, interpretation of data, or writing the manuscript.

\section{Authors' contributions}


Conceptualisation: AEA. Study design: AEA, CR, HM, BG. Data analysis: AEA NGP. Interpretation of data: $A E A, H M, B G, C R, B N, E W, M K, J T$. Drafting the manuscript: AEA, BG, HM, MK, BN, EW, CR, JT. Funding acquisition: AEA

\section{Acknowledgements}

The authors thank Nils-Gunnar Persson (NGP) for statistical advice and analysis and Lisbeth Sjöstedt for meticulous data validation.

\section{References}

1. Andersson AE, Bergh I, Karlsson J, Nilsson K. Patients' experiences of acquiring a deep surgical site infection: An interview study. American Journal of Infection Control. 2010;38(9):711-7.

2. Pollmann CT, Dahl FA, Røtterud JHM, Gjertsen JE, Årøen A. Surgical site infection after hip fracture mortality and risk factors: an observational cohort study of 1,709 patients. Acta Orthop. 2020;91(3):347-52.

3. Noailles T, Brulefert K, Chalopin A, Longis PM, Gouin F. What are the risk factors for post-operative infection after hip hemiarthroplasty? Systematic review of literature. (1432-5195 (Electronic)).

4. de Jong L, Klem T, Kuijper TM, Roukema GR. Factors affecting the rate of surgical site infection in patients after hemiarthroplasty of the hip following a fracture of the neck of the femur. (2049-4408 (Electronic)).

5. Liu X, Dong Z, Li J, Feng Y, Cao G, Song X, et al. Factors affecting the incidence of surgical site infection after geriatric hip fracture surgery: a retrospective multicenter study. J Orthop Surg Res. 2019;14(1):382.

6. Acklin YP, Widmer AF, Renner RM, Frei R, Gross $T$. Unexpectedly increased rate of surgical site infections following implant surgery for hip fractures: problem solution with the bundle approach. Injury. 2011;42(2):209-16.

7. Sullivan NPT, Hughes AW, Halliday RL, Ward AL, Chesser TJS. Early complications following cemented modular hip hemiarthroplasty. The open orthopaedics journal. 2015;9(1):15.

8. Zajonz D, Brand A, Lycke C, Özkurtul O, Theopold J, Spiegl UJA, et al. Risk factors for early infection following hemiarthroplasty in elderly patients with a femoral neck fracture. Eur J Trauma Emerg Surg. 2019;45(2):207-12.

9. Lin HS, Watts JN, Peel NM, Hubbard RE. Frailty and post-operative outcomes in older surgical patients: a systematic review. BMC Geriatr. 2016;16(1):157.

10. Kaye KS, Sloane R, Sexton DJ, Schmader KA. Risk factors for surgical site infections in older people. J Am Geriatr Soc. 2006;54(3):391-6.

11. Erichsen Andersson A, Bergh I, Eriksson B, Karlsson J, Nilsson K. The application of evidence-based measures to reduce surgical site infections during orthopedic surgery - report of a single-center experience in Sweden. Patient Saf Surg. 2012;6(1):11. 
12. Andersson AE, Bergh I, Karlsson J, Eriksson BI, Nilsson K. The application of evidence-based measures to reduce surgical site infections during orthopedic surgery - report of a single-center experience in Sweden. Patient Saf Surg. 2012;6(1):11.

13. Megeus V, Nilsson K, Eriksson B, Karlsson J, Andersson Erichsen A. Hand hygiene and aseptic techniques during routine anesthetic care - observations in the operating room. Antimicrobial Resistance and Infection Control. 2015;4(5).

14. Megeus V, Nilsson K, Karlsson J, Eriksson B, Andersson E. Hand contamination, cross-transmission and risk-associated behaviors - an observational study of team members in operating rooms. Accepted for publication in AORN 2015-04 20. 2015.

15. Andersson EA GW, Nilsson K,. Improving Care in Surgery - A Qualitative study of Managers' Experiences of Implementing Evidence-Based Practice in the Operating Room. Journal of Hospital Adminstration. 2015;4(4).

16. Erichsen Andersson A, Frodin M, Dellenborg L, Wallin L, Hok J, Gillespie BM, et al. Iterative co-creation for improved hand hygiene and aseptic techniques in the operating room: experiences from the safe hands study. BMC Health Serv Res. 2018;18(1):2.

17. Wikstrom E, Dellenborg L, Wallin L, Gillespie BM, Erichsen Andersson A. The Safe Hands Study: Implementing aseptic techniques in the operating room: Facilitating mechanisms for contextual negotiation and collective action. American Journal of Infection Control. 2019;47(3):251-7.

18. von Elm E, Altman DG, Egger M, Pocock SJ, Gøtzsche PC, Vandenbroucke JP. The Strengthening the Reporting of Observational Studies in Epidemiology (STROBE) statement: guidelines for reporting observational studies. PLoS medicine. 2007;4(10):e296.

19. Noailles T, Brulefert K, Chalopin A, Longis PM, Gouin F. What are the risk factors for post-operative infection after hip hemiarthroplasty? Systematic review of literature. Int Orthop. 2016;40(9):1843-8.

20. Johnson B, Starks I, Bancroft G, Roberts PJ. The effect of care bundle development on surgical site infection after hemiarthroplasty: an 8-year review. J Trauma Acute Care Surg. 2012;72(5):1375-9.

21. Tocchi C, Dixon J, Naylor M, Jeon S, McCorkle R. Development of a frailty measure for older adults: the frailty index for elders. J Nurs Meas. 2014;22(2):223-40.

22. Chu VH, Crosslin DR, Friedman JY, Reed SD, Cabell CH, Griffiths RI, et al. Staphylococcus aureus bacteremia in patients with prosthetic devices: costs and outcomes. Am J Med. 2005;118(12):1416.

23. Pittet D, Allegranzi B, Sax H, Dharan S, Pessoa-Silva CL, Donaldson L, et al. Evidence-based model for hand transmission during patient care and the role of improved practices. The Lancet Infectious Diseases. 2006;6(10):641-52.

24. Murdoch DR, Roberts SA, Fowler VG, Jr., Shah MA, Taylor SL, Morris AJ, et al. Infection of orthopedic prostheses after Staphylococcus aureus bacteremia. Clin Infect Dis. 2001;32(4):647-9.

25. Sendi P, Banderet F, Graber P, Zimmerli W. Periprosthetic joint infection following Staphylococcus aureus bacteremia. J Infect. 2011;63(1):17-22.

26. Honkanen M, Jämsen E, Karppelin M, Huttunen R, Eskelinen A, Syrjänen J. Periprosthetic Joint Infections as a Consequence of Bacteremia. Open Forum Infect Dis. 2019;6(6):ofz218. 
27. Ruus C, Skovbjerg S, Magnusson T, Snygg-Martin U, Studahl M, Andersson LM. Tidig infektionskonsult gav effekt vid Staphylococcus aureus-bakteriemi - Konsultationen minskade återinläggningsfrekvens och mortalitet, visar retrospektiv studie. Lakartidningen. 2018;115.

28. Schmitt S, McQuillen DP, Nahass R, Martinelli L, Rubin M, Schwebke K, et al. Infectious diseases specialty intervention is associated with decreased mortality and lower healthcare costs. Clin Infect Dis. 2014;58(1):22-8.

29. Gillespie BM, Chaboyer WP, Mclnnes E, Kent B, Whitty JA, Thalib L. Repositioning for pressure ulcer prevention in adults. Cochrane Database Syst Rev. 2014;2014(4):Cd009958.

30. Furuya EY, Dick A, Perencevich EN, Pogorzelska M, Goldmann D, Stone PW. Central line bundle implementation in US intensive care units and impact on bloodstream infections. PLoS One. 2011;6(1):e15452.

31. Pogorzelska M, Stone PW, Furuya EY, Perencevich EN, Larson EL, Goldmann D, et al. Impact of the ventilator bundle on ventilator-associated pneumonia in intensive care unit. Int $\mathrm{J}$ Qual Health Care. 2011;23(5):538-44.

32. Gould D, Moralejo D, Drey N, Chudleigh J, Taljaard M. Interventions to improve hand hygiene compliance in patient care: Reflections on three systematic reviews for the Cochrane Collaboration 2007-2017. J Infect Prev. 2018;19(3):108-13.

33. Doran D, Haynes BR, Estabrooks CA, Kushniruk A, Dubrowski A, Bajnok I, et al. The role of organizational context and individual nurse characteristics in explaining variation in use of information technologies in evidence based practice. Implement Sci. 2012;7:122.

34. Damschroder LJ, Aron DC, Keith RE, Kirsh SR, Alexander JA, Lowery JC. Fostering implementation of health services research findings into practice: a consolidated framework for advancing implementation science. Implement Sci. 2009;4:50.

35. Gagliardi AR, Webster F, Brouwers MC, Baxter NN, Finelli A, Gallinger S. How does context influence collaborative decision-making for health services planning, delivery and evaluation? BMC Health Serv Res. 2014;14:545.

36. Rycroft-Malone J, Seers K, Chandler J, Hawkes CA, Crichton N, Allen C, et al. The role of evidence, context, and facilitation in an implementation trial: implications for the development of the PARIHS framework. Implement Sci. 2013;8:28.

37. Harvey G, Loftus-Hills A, Rycroft-Malone J, Titchen A, Kitson A, McCormack B, et al. Getting evidence into practice: the role and function of facilitation. J Adv Nurs. 2002;37(6):577-88.

38. Dogherty EJ, Harrison MB, Graham ID. Facilitation as a role and process in achieving evidence-based practice in nursing: a focused review of concept and meaning. Worldviews Evid Based Nurs. 2010;7(2):76-89.

39. Isaacs WN. Creating a shared field of meaning: An action theory of dialogue. In: Roberts NC, editor. The Transformative Power of Dialogue,. Research in Public Policy Analysis and Management: Emerald Group Publishing Limited; 2002. p. 203-41. 
40. Schein EH. On dialogue, culture, and organizational learning. IEEE Engineering Management Review. 1995;23(1):23-9.

41. Schein E. Organizational Culture and Leadership: Wiley; 2010.

42. Schein EH. Reactions, Reflections, Rejoinders, and a Challenge. The Journal of Applied Behavioral Science. 2009;45(1):141-58.

43. Nembhard IM, Edmondson AC. Making it safe: The effects of leader inclusiveness and professional status on psychological safety and improvement efforts in health care teams. Journal of Organizational Behavior. 2006;27(7):941-66.

\section{Tables}

Box 1. Variables and definitions 


\begin{tabular}{|c|c|}
\hline Age & Years \\
\hline Gender & Female/male \\
\hline \multirow[t]{3}{*}{ Surgical method } & Total arthroplasty \\
\hline & Hemiarthroplasty \\
\hline & Internal fixation with osteosynthesis \\
\hline \multirow{5}{*}{$\begin{array}{l}\text { American Society of } \\
\text { Anaesthesiologists' (ASA) } \\
\text { classification of physical health }\end{array}$} & I-IV \\
\hline & ASA I-no systemic disease \\
\hline & ASA II-mild systemic disease \\
\hline & ASA III-moderate systemic disease \\
\hline & ASA IV-severe systemic disease that is a constant threat to life \\
\hline \multirow[t]{2}{*}{ Early surgical site infection } & $\begin{array}{l}\text { a) Development of a superficial or deep infection in the } \\
\text { surgical wound any time up to hospital discharge }\end{array}$ \\
\hline & $\begin{array}{l}\text { b) Diagnosed by a physician and treated with antibiotics with } \\
\text { or without surgical revision }\end{array}$ \\
\hline \multirow[t]{2}{*}{$\begin{array}{l}\text { Urinary tract infection, pneumonia } \\
\text { and sepsis }\end{array}$} & $\begin{array}{l}\text { Data were extracted from diagnosis codes at discharge from } \\
\text { the hospital and based on physician diagnosis and treated } \\
\text { with antibiotics. }\end{array}$ \\
\hline & $\begin{array}{l}\text { Infections were deemed as hospital related if they occurred }>2 \\
\text { days after admission to hospital. }\end{array}$ \\
\hline Cognitive failure & Including temporary impairment and dementia \\
\hline Diabetes & Type II: any type of treatment \\
\hline Pressure ulcer & Norton stage I-IV \\
\hline Intact skin & Recorded on admission \\
\hline Time to surgery & $\begin{array}{l}\text { Measured from in-hospital diagnosis to surgery dichotomised: } \\
<\text { or }>36 \text { hours }\end{array}$ \\
\hline Housing before hospitalisation & Home or nursing home \\
\hline
\end{tabular}

Table 1. Timeline of the Safe Hands project (blue) and changes in standard practices. 
Year and

quarters

Interventions and changes in routines

1 Baseline -Systematic collection of outcome data and related variable after hip fracture surgery

Q1-2

Q 3-4 - Introduction of the Safe Hands project (ClinicalTrials.gov ID: NCT02983136) to secure leadership commitment to infection prevention in surgery

A new routine promoting early assessment by the consulting infectious diseases specialist in Staphylococcus aureus bacteraemia was introduced.

2

Intervention

-The Safe Hands project was launched in the OR.

Q1-2

Q3-4

-A new routine was implemented that formalised the practice that junior physicians in training should receive support from a senior surgeon to avoid prolonged surgical time for hip fracture surgery. The aim was to create a culture where it would be easy and appropriate to ask for help from a senior.

3

Intervention

-Antibiotic rounds twice weekly led by a consulting infectious diseases specialist

Q1-2 were introduced on the geriatric wards with the aim of promoting sound antibiotic use, e.g. reducing the number of prophylaxis-resistant bacterial strains on the wards.

-Accessibility to the consulting infectious diseases specialist was increased from two to four days a week for bedside assessments.

- The preoperative shower routine consisting of a double shower with $4 \%$ chlorhexidine gluconate ( $\mathrm{CHX}$ ) was changed from two showers before surgery to one shower before surgery.

If the patient had to wait for surgery for more than 48 hours after the first shower, an additional $\mathrm{CHX}$ treatment was carried out.

-Expanding the Safe Hands project; a catheter-related urinary tract infection prevention strategy (Safe Bladder) was developed.

Q3-4

- Safe Bladder was implemented in the full care pathway ER, OR, PACU and the geriatric wards. 
4. Post-

intervention

Q1-2

Q 3-4

5 Post- $\quad-$ The antibiotic rounds led by a consulting infectious diseases specialist were intervention reduced from twice to once weekly.

Q1-2

Q3-4

Table 2. Included and excluded subjects with reasons in years 1-5

\begin{tabular}{|c|c|c|c|c|c|}
\hline \multirow[t]{2}{*}{ Period } & Year 1 & Year 2 & Year 3 & Year 4 & Year 5 \\
\hline & Baseline & Intervention & Intervention & Follow-up & Follow-up \\
\hline Eligible & $n=461$ & $n=833$ & $\mathrm{n}=842$ & $\mathrm{n}=775$ & $\mathrm{n}=741$ \\
\hline $\begin{array}{l}\text { Total } \\
\text { excluded }\end{array}$ & $n=16$ & $n=23$ & $n=21$ & $n=5$ & $n=3$ \\
\hline $\begin{array}{l}\text { Reasons } \\
\text { for } \\
\text { exclusion }\end{array}$ & $\begin{array}{l}\text { Surgery at another } \\
\text { hospital, } n=8 \\
\text { Wrong fracture, } n \\
=5 \\
\text { Girdlestone, } \\
n=3\end{array}$ & $\begin{array}{l}\text { Wrong } \\
\text { fracture, } \mathrm{n}= \\
4 \\
\text { Girdlestone, } \\
\mathrm{n}=3 \\
\text { Registered } \\
\text { twice, } \mathrm{n}=7 \\
<65 \text { years } \\
\text { of age, } \mathrm{n}=3 \\
<2 \text { HLOS }^{1}, \\
\mathrm{n}=3\end{array}$ & $\begin{array}{l}\text { Surgery at another } \\
\text { hospital, } n=3 \\
\text { Wrong fracture, } \\
\mathrm{n}=5 \\
\text { Girdlestone, } \mathrm{n}=6 \\
<65 \text { years of age, } \\
\mathrm{n}=2 \\
<2 \operatorname{HLOS}^{1}, \mathrm{n}=5\end{array}$ & $\begin{array}{l}\text { Wrong } \\
\text { fracture, } n= \\
2 \\
<65 \text { years } \\
\text { of age, } n=2 \\
<2 \text { HLOS }^{1}, \\
n=1\end{array}$ & $\begin{array}{l}\text { Wrong } \\
\text { fracture } \\
n=1 \\
<65 \text { years } \\
\text { of age }=1 \\
<2 \text { HLOS }^{1} \\
=1\end{array}$ \\
\hline Included & $\mathrm{n}=442$ & $\mathrm{n}=820$ & $n=806$ & $N=733$ & $\mathrm{n}=712$ \\
\hline $\begin{array}{l}\text { Total } \\
\text { sample }\end{array}$ & $N=3553$ & & & & \\
\hline
\end{tabular}

Table 3. Patient characteristics and clinical data over five years

${ }^{1}$ In-dwelling Urinary Catheter (UTC) 
Variable

$\begin{array}{llllll}1 & 2 & 3 & 4 & 5 & \text { p- } \\ (n=442) & (n=820) & (n=806) & (n=773) & (n=712) & \text { value }\end{array}$

Baseline Intervention Intervention Follow- Follow-

up up

\section{Patient characteristics}

\begin{tabular}{|c|c|c|c|c|c|c|}
\hline Women & $\begin{array}{l}312 \\
(70.6 \%)\end{array}$ & $\begin{array}{l}547 \\
(66.7 \%)\end{array}$ & $\begin{array}{l}551 \\
(68.4 \%)\end{array}$ & $\begin{array}{l}540 \\
(69.9 \%)\end{array}$ & $\begin{array}{l}490 \\
(68.8 \%)\end{array}$ & 0.77 \\
\hline Age & $\begin{array}{l}83.5 \\
(8.2) \\
84.5 \\
(65 ; 101) \\
n=442\end{array}$ & $\begin{array}{l}84.5(7.8) \\
85(65 ; \\
102) \\
n=820\end{array}$ & $\begin{array}{l}83.8(8.2) \\
85(65 ; \\
101) \\
n=806\end{array}$ & $\begin{array}{l}83.8 \\
(8.3) \\
85(65 ; \\
102) \\
n=773\end{array}$ & $\begin{array}{l}83.6 \\
(8.3) \\
84(65 ; \\
104) \\
n=712\end{array}$ & 0.19 \\
\hline ASA classification I & $\begin{array}{l}20 \\
(4.5 \%)\end{array}$ & $15(1.8 \%)$ & $14(1.7 \%)$ & $\begin{array}{l}30 \\
(3.9 \%)\end{array}$ & $\begin{array}{l}17 \\
(2.4 \%)\end{array}$ & \\
\hline II & $\begin{array}{l}180 \\
(40.7 \%)\end{array}$ & $\begin{array}{l}334 \\
(40.8 \%)\end{array}$ & $\begin{array}{l}289 \\
(35.9 \%)\end{array}$ & $\begin{array}{l}315 \\
(40.9 \%)\end{array}$ & $\begin{array}{l}286 \\
(40.5 \%)\end{array}$ & \\
\hline III & $\begin{array}{l}211 \\
(47.7 \%)\end{array}$ & $\begin{array}{l}410 \\
(50.1 \%)\end{array}$ & $\begin{array}{l}448 \\
(55.6 \%)\end{array}$ & $\begin{array}{l}382 \\
(49.6 \%)\end{array}$ & $\begin{array}{l}355 \\
(50.2 \%)\end{array}$ & \\
\hline IV & $\begin{array}{l}31 \\
(7.0 \%)\end{array}$ & $60(7.3 \%)$ & $55(6.8 \%)$ & $\begin{array}{l}43 \\
(5.6 \%)\end{array}$ & $\begin{array}{l}49 \\
(6.9 \%)\end{array}$ & 0.88 \\
\hline Diabetes & $\begin{array}{l}61 \\
(13.8 \%)\end{array}$ & $\begin{array}{l}126 \\
(15.4 \%)\end{array}$ & $\begin{array}{l}128 \\
(15.9 \%)\end{array}$ & $\begin{array}{l}133 \\
(17.2 \%)\end{array}$ & $\begin{array}{l}123 \\
(17.3 \%)\end{array}$ & 0.072 \\
\hline Cognitive failure & $\begin{array}{l}125 \\
(28.3 \%)\end{array}$ & $\begin{array}{l}267 \\
(32.6 \%)\end{array}$ & $\begin{array}{l}352 \\
(43.7 \%)\end{array}$ & $\begin{array}{l}315 \\
(40.8 \%)\end{array}$ & $\begin{array}{l}258 \\
(36.2 \%)\end{array}$ & 0.0005 \\
\hline $\begin{array}{l}\text { Housing } \\
\text { Home }\end{array}$ & $\begin{array}{l}370 \\
(83.7 \%)\end{array}$ & $\begin{array}{l}573 \\
(69.9 \%)\end{array}$ & $\begin{array}{l}568 \\
(70.5 \%)\end{array}$ & $\begin{array}{l}516 \\
(66.8 \%)\end{array}$ & $\begin{array}{l}504 \\
(70.8 \%)\end{array}$ & \\
\hline Nursing home & $\begin{array}{l}72 \\
(16.3 \%)\end{array}$ & $\begin{array}{l}247 \\
(30.1 \%)\end{array}$ & $\begin{array}{l}238 \\
(29.5 \%)\end{array}$ & $\begin{array}{l}257 \\
(33.2 \%)\end{array}$ & $\begin{array}{l}208 \\
(29.2 \%)\end{array}$ & $<.0001$ \\
\hline Intact skin on admission & $\begin{array}{l}291 \\
(66.6 \%)\end{array}$ & $\begin{array}{l}525 \\
(64.9 \%)\end{array}$ & $\begin{array}{l}496 \\
(62.2 \%)\end{array}$ & $\begin{array}{l}514 \\
(66.9 \%)\end{array}$ & $\begin{array}{l}457 \\
(64.2 \%)\end{array}$ & 0.81 \\
\hline
\end{tabular}

Clinical data

\begin{tabular}{|c|c|c|c|c|c|}
\hline $\begin{array}{l}\text { Time to surgery from } \\
\text { admission (hours) } \\
<36\end{array}$ & $\begin{array}{l}399 \\
(90.3 \%)\end{array}$ & $\begin{array}{l}702 \\
(85.7 \%)\end{array}$ & $\begin{array}{l}641 \\
(79.5 \%)\end{array}$ & $\begin{array}{l}627 \\
(81.1 \%)\end{array}$ & $\begin{array}{l}626 \\
(88.0 \%)\end{array}$ \\
\hline$>36$ & $\begin{array}{l}43 \\
(9.7 \%)\end{array}$ & $\begin{array}{l}117 \\
(14.3 \%)\end{array}$ & $\begin{array}{l}165 \\
(20.5 \%)\end{array}$ & $\begin{array}{l}146 \\
(18.9 \%)\end{array}$ & $\begin{array}{l}85 \\
(12.0 \%)\end{array}$ \\
\hline
\end{tabular}




\begin{tabular}{|c|c|c|c|c|c|c|}
\hline \multirow[t]{2}{*}{ Variable } & ${ }^{1}(n=442)$ & ${ }_{(n=820)}^{2}$ & ${ }^{3}(n=806)$ & $\stackrel{4}{(n=773)}$ & $\begin{array}{l}5 \\
(n=712)\end{array}$ & \multirow[t]{2}{*}{$\begin{array}{l}\mathrm{p}- \\
\text { value }\end{array}$} \\
\hline & Baseline & Intervention & Intervention & $\begin{array}{l}\text { Follow- } \\
\text { up }\end{array}$ & $\begin{array}{l}\text { Follow- } \\
\text { up }\end{array}$ & \\
\hline Length of surgery & $\begin{array}{l}75.1 \\
(34.3) \\
72(9 \\
226) \\
n=442\end{array}$ & $\begin{array}{l}73.7(32.4) \\
70(13 ; \\
208) \\
n=820\end{array}$ & $\begin{array}{l}70.2(30.4) \\
69(9 ; 248) \\
\mathrm{n}=805\end{array}$ & $\begin{array}{l}75.8 \\
(34.3) \\
74(11 ; \\
222) \\
n=773\end{array}$ & $\begin{array}{l}71.5 \\
(30.0) \\
69.5 \\
(13 ; \\
174) \\
n=712\end{array}$ & 0.71 \\
\hline Length of hospital stay & $\begin{array}{l}14.3 \\
(7.3) \\
13(3 \\
60) \\
n=442\end{array}$ & $\begin{array}{l}13.6(7.6) \\
13(2 ; 68) \\
n=820\end{array}$ & $\begin{array}{l}12.4(7.7) \\
11(2 ; 133) \\
\mathrm{n}=806\end{array}$ & $\begin{array}{l}10.7 \\
(5.4) \\
10(3 ; \\
46) \\
n=772\end{array}$ & $\begin{array}{l}9.7 \\
(4.76) \\
9(2 ; \\
44) \\
n=712\end{array}$ & $<.0001$ \\
\hline \multicolumn{7}{|l|}{ Surgical method } \\
\hline Total arthroplasty & $\begin{array}{l}44 \\
(10.0 \%)\end{array}$ & 75 (9.1\%) & $88(11.1 \%)$ & $\begin{array}{l}83 \\
(10.8 \%)\end{array}$ & $\begin{array}{l}65 \\
(9.1 \%)\end{array}$ & \\
\hline Hemiarthroplasty & $\begin{array}{l}134 \\
(30.3 \%)\end{array}$ & $\begin{array}{l}274 \\
(33.4 \%)\end{array}$ & $\begin{array}{l}247 \\
(31.1 \%)\end{array}$ & $\begin{array}{l}244 \\
(31.9 \%)\end{array}$ & $\begin{array}{l}218 \\
(30.6 \%)\end{array}$ & \\
\hline Internal fixation & $\begin{array}{l}264 \\
(59.7 \%)\end{array}$ & $\begin{array}{l}470 \\
(57.3 \%)\end{array}$ & $\begin{array}{l}459 \\
(57.8 \%)\end{array}$ & $\begin{array}{l}439 \\
(57.3 \%)\end{array}$ & $\begin{array}{l}426 \\
(59.8 \%)\end{array}$ & 0.74 \\
\hline Missing & $0(0.0 \%)$ & $1(0.1 \%)$ & $0(0.0 \%)$ & $0(0.0 \%)$ & $3(0.4 \%)$ & \\
\hline $\begin{array}{l}\text { In-dwelling UTC }{ }^{1} \text { more } \\
\text { than once }\end{array}$ & $\begin{array}{l}24 \\
(10.7 \%)\end{array}$ & $83(15.7 \%)$ & $\begin{array}{l}101 \\
(18.2 \%)\end{array}$ & $\begin{array}{l}76 \\
(11.2 \%)\end{array}$ & $\begin{array}{l}82 \\
(12.8 \%)\end{array}$ & 0.22 \\
\hline
\end{tabular}

For categorical variables, $\mathrm{n}(\%)$ is presented.

For continuous variables, the mean (SD)/median (range) $/ \mathrm{n}=$ is presented.

For comparisons between groups, the Mantel-Haenszel chi square test was

used for ordered categorical variables and the Jonckheere-Terpstra

test was used for continuous variables.

Table 4. Infectious outcomes over five years 


\begin{tabular}{|c|c|c|c|c|c|c|}
\hline \multirow[t]{2}{*}{ Variable } & ${ }^{1}(n=442)$ & $\begin{array}{l}\text { year } 2 \\
(n=820)\end{array}$ & $\begin{array}{l}\text { year } 3 \\
(n=806)\end{array}$ & $\begin{array}{l}\text { year } 4 \\
(n=773)\end{array}$ & $\begin{array}{l}\text { year } 5 \\
(n=712)\end{array}$ & \multirow[t]{2}{*}{$\begin{array}{l}\mathrm{p} \text { - } \\
\text { value }\end{array}$} \\
\hline & Baseline & Intervention & Intervention & $\begin{array}{l}\text { Follow- } \\
\text { up }\end{array}$ & $\begin{array}{l}\text { Follow- } \\
\text { up }\end{array}$ & \\
\hline SSI ${ }^{1}$ & $13(2.9 \%)$ & $18(2.2 \%)$ & $19(2.4 \%)$ & $9(1.2 \%)$ & $8(1.1 \%)$ & 0.0079 \\
\hline $\mathrm{UTI}^{2}$ & $\begin{array}{l}75 \\
(17.0 \%)\end{array}$ & $\begin{array}{l}104 \\
(12.7 \%)\end{array}$ & 58 (7.2\%) & $\begin{array}{l}31 \\
(4.0 \%)\end{array}$ & $\begin{array}{l}31 \\
(4.4 \%)\end{array}$ & $<.0001$ \\
\hline Sepsis & $13(2.9 \%)$ & $21(2.6 \%)$ & $23(2.9 \%)$ & $\begin{array}{l}12 \\
(1.6 \%)\end{array}$ & $8(1.1 \%)$ & 0.0094 \\
\hline Pneumonia & 35 (7.9\%) & $71(8.7 \%)$ & $48(6.0 \%)$ & $\begin{array}{l}45 \\
(5.8 \%)\end{array}$ & $\begin{array}{l}63 \\
(8.9 \%)\end{array}$ & 0.76 \\
\hline Covid-19 & $0(0.0 \%)$ & $0(0.0 \%)$ & $0(0.0 \%)$ & $0(0.0 \%)$ & $\begin{array}{l}12 \\
(1.7 \%)\end{array}$ & \\
\hline $\begin{array}{l}\text { Any type of infection } \\
\text { except SSI }\end{array}$ & $\begin{array}{l}124 \\
(28.1 \%)\end{array}$ & $\begin{array}{l}216 \\
(26.3 \%)\end{array}$ & $\begin{array}{l}163 \\
(20.2 \%)\end{array}$ & $\begin{array}{l}111 \\
(14.4 \%)\end{array}$ & $\begin{array}{l}131 \\
(18.4 \%)\end{array}$ & $<.0001$ \\
\hline $\begin{array}{l}\text { For categorical variab } \\
\text { For comparisons betv } \\
\text { categorical variables. }\end{array}$ & $\begin{array}{l}(\%) \text { is pres } \\
\text { groups, the }\end{array}$ & $\begin{array}{l}\text { ted. } \\
\text { lantel-Haen }\end{array}$ & chi square & was use & or ordered & \\
\hline
\end{tabular}

${ }^{1}$ Surgical site infections, ${ }^{2}$ Urinary tract infection requiring medical treatment

Table 5. Univariable predictions of SSI adjusted by age and gender 


\begin{tabular}{|c|c|c|c|c|c|c|c|}
\hline \multirow[b]{2}{*}{ Variable and values } & \multirow[b]{2}{*}{$\begin{array}{l}n(\%) \text { of } \\
\text { events }\end{array}$} & \multicolumn{3}{|c|}{ Univariable* } & \multicolumn{3}{|c|}{ Adjusted** } \\
\hline & & $\begin{array}{l}\text { OR } \\
(95 \% \mathrm{Cl})\end{array}$ & $\mathrm{p}$-value & $\begin{array}{l}\text { Area } \\
\text { under } \\
\text { ROC } \\
\text { curve } \\
(95 \% \mathrm{Cl})\end{array}$ & $\begin{array}{l}\text { OR } \\
(95 \% \mathrm{Cl})\end{array}$ & $\mathrm{p}$-value & $\mathrm{m}^{1}$ \\
\hline Year ${ }_{1}^{1-5}$ & $\begin{array}{l}13 \\
(2.9 \%)\end{array}$ & & & & & & \\
\hline 2 & $\begin{array}{l}18 \\
(2.2 \%)\end{array}$ & & & & & & \\
\hline 3 & $\begin{array}{l}19 \\
(2.4 \%)\end{array}$ & & & & & & \\
\hline 4 & $\begin{array}{l}9 \\
(1.2 \%)\end{array}$ & & & & & & \\
\hline 5 & $\begin{array}{l}8 \\
(1.1 \%)\end{array}$ & $\begin{array}{l}0.78 \\
(0.64- \\
0.94)\end{array}$ & 0.0086 & $\begin{array}{l}0.59 \\
(0.53- \\
0.66)\end{array}$ & $\begin{array}{l}0.78 \\
(0.64- \\
0.94)\end{array}$ & 0.0092 & \\
\hline $\begin{array}{l}\text { Gender } \\
\text { female }\end{array}$ & $\begin{array}{l}36 \\
(1.5 \%)\end{array}$ & & & & & & 0 \\
\hline male & $\begin{array}{l}31 \\
(2.8 \%)\end{array}$ & $\begin{array}{l}1.91 \\
(1.18- \\
3.11)\end{array}$ & 0.0088 & $\begin{array}{l}0.58 \\
(0.52- \\
0.64)\end{array}$ & $\begin{array}{l}1.97 \\
(1.21- \\
3.22)\end{array}$ & 0.0066 & \\
\hline $\begin{array}{l}\mathrm{Age} \\
65<81\end{array}$ & $\begin{array}{l}22 \\
(1.9 \%)\end{array}$ & & & & & & 0 \\
\hline $81<89$ & $\begin{array}{l}22 \\
(1.7 \%)\end{array}$ & & & & & & \\
\hline 89-104 & $\begin{array}{l}23 \\
(2.0 \%)\end{array}$ & $\begin{array}{l}1.01 \\
(0.98- \\
1.04)\end{array}$ & 0.57 & $\begin{array}{l}0.52 \\
(0.45- \\
0.59)\end{array}$ & $\begin{array}{l}1.01 \\
(0.98- \\
1.05)\end{array}$ & 0.37 & \\
\hline ASA & $\begin{array}{l}0 \\
(0.0 \%)\end{array}$ & & & & & & 9 \\
\hline II & $\begin{array}{l}19 \\
(1.4 \%)\end{array}$ & & & & & & \\
\hline III & $\begin{array}{l}43 \\
(2.4 \%)\end{array}$ & & & & & & \\
\hline IV & $\begin{array}{l}5 \\
(2.1 \%)\end{array}$ & $\begin{array}{l}1.52 \\
(1.05- \\
2.21)\end{array}$ & 0.027 & $\begin{array}{l}0.57 \\
(0.52- \\
0.63)\end{array}$ & $\begin{array}{l}1.41 \\
(0.96- \\
2.06)\end{array}$ & 0.078 & \\
\hline
\end{tabular}




\begin{tabular}{|c|c|c|c|c|c|c|c|}
\hline $\begin{array}{l}\text { Diabetes } \\
\text { yes }\end{array}$ & $\begin{array}{l}12 \\
(2.1 \%)\end{array}$ & & & & & & 0 \\
\hline no & $\begin{array}{l}55 \\
(1.8 \%)\end{array}$ & $\begin{array}{l}0.88 \\
(0.47- \\
1.65)\end{array}$ & 0.68 & $\begin{array}{l}0.51 \\
(0.46- \\
0.56)\end{array}$ & $\begin{array}{l}0.93 \\
(0.49- \\
1.75)\end{array}$ & 0.81 & \\
\hline $\begin{array}{l}\text { Hospital length of } \\
\text { stay (days) } \\
2<9\end{array}$ & $\begin{array}{l}8 \\
(0.7 \%)\end{array}$ & & & & & & \\
\hline $9<14$ & $\begin{array}{l}10( \\
0.8 \%)\end{array}$ & & & & & & \\
\hline $14-133$ & $\begin{array}{l}49 \\
(4.3 \%)\end{array}$ & $\begin{array}{l}1.11 \\
(1.09- \\
1.13)\end{array}$ & $<0.0001$ & $\begin{array}{l}0.76 \\
(0.70- \\
0.82)\end{array}$ & $\begin{array}{l}1.11 \\
(1.08- \\
1.13)\end{array}$ & $<0.0001$ & 1 \\
\hline $\begin{array}{l}\text { Cognitive failure } \\
\text { yes }\end{array}$ & $\begin{array}{l}25 \\
(1.9 \%)\end{array}$ & & & & & & 1 \\
\hline no & $\begin{array}{l}42 \\
(1.9 \%)\end{array}$ & $\begin{array}{l}0.99 \\
(0.60- \\
1.63)\end{array}$ & 0.97 & $\begin{array}{l}0.50 \\
(0.44- \\
0.56)\end{array}$ & $\begin{array}{l}1.05 \\
(0.63- \\
1.75)\end{array}$ & 0.84 & \\
\hline $\begin{array}{l}\text { Time to surgery } \\
<36 \mathrm{~h}\end{array}$ & $\begin{array}{l}51 \\
(1.7 \%)\end{array}$ & & & & & & 2 \\
\hline$>36 \mathrm{~h}$ & $\begin{array}{l}16 \\
(2.9 \%)\end{array}$ & $\begin{array}{l}1.71 \\
(0.97- \\
3.02)\end{array}$ & 0.065 & $\begin{array}{l}0.54 \\
(0.49- \\
0.59)\end{array}$ & $\begin{array}{l}1.72 \\
(0.97- \\
3.05)\end{array}$ & 0.064 & \\
\hline $\begin{array}{l}\text { Procedure time, } \\
\text { minutes } 9-<57\end{array}$ & $\begin{array}{l}17 \\
(1.4 \%)\end{array}$ & & & & & & 1 \\
\hline $57<85$ & $\begin{array}{l}14 \\
(1.2 \%)\end{array}$ & & & & & & \\
\hline $85-248$ & $\begin{array}{l}35 \\
(2.9 \%)\end{array}$ & $\begin{array}{l}1.29 \\
(1.05- \\
1.59)\end{array}$ & 0.013 & $\begin{array}{l}0.59 \\
(0.51- \\
0.66)\end{array}$ & $\begin{array}{l}1.31 \\
(1.07- \\
1.62)\end{array}$ & 0.0095 & \\
\hline $\begin{array}{c}\text { Pressure ulcers, } \\
\text { Norton scale 1-4 } \\
1 \text { vs no }\end{array}$ & $\begin{array}{l}8 \\
(4.4 \%)\end{array}$ & $\begin{array}{l}2.10 \\
(0.95- \\
4.63)\end{array}$ & 0.066 & & $\begin{array}{l}2.06 \\
(0.93- \\
4.56)\end{array}$ & 0.076 & $1732^{2}$ \\
\hline 2 vs no & $\begin{array}{l}2 \\
(1.8 \%)\end{array}$ & $\begin{array}{l}0.83 \\
(0.20- \\
3.50)\end{array}$ & 0.80 & & $\begin{array}{l}0.82 \\
(0.19- \\
3.48)\end{array}$ & 0.79 & \\
\hline 3 vs no & $\begin{array}{l}1 \\
(6.7 \%)\end{array}$ & $\begin{array}{l}3.28 \\
(0.42- \\
25.71)\end{array}$ & 0.26 & & $\begin{array}{l}3.37 \\
(0.43- \\
26.59)\end{array}$ & 0.25 & \\
\hline 4 vs no & $\begin{array}{l}2 \\
(25.0 \%)\end{array}$ & $\begin{array}{l}15.31 \\
(2.98-\end{array}$ & 0.0011 & $\begin{array}{l}0.57 \\
(0.50-\end{array}$ & $\begin{array}{l}13.26 \\
(2.53-\end{array}$ & 0.0022 & \\
\hline
\end{tabular}




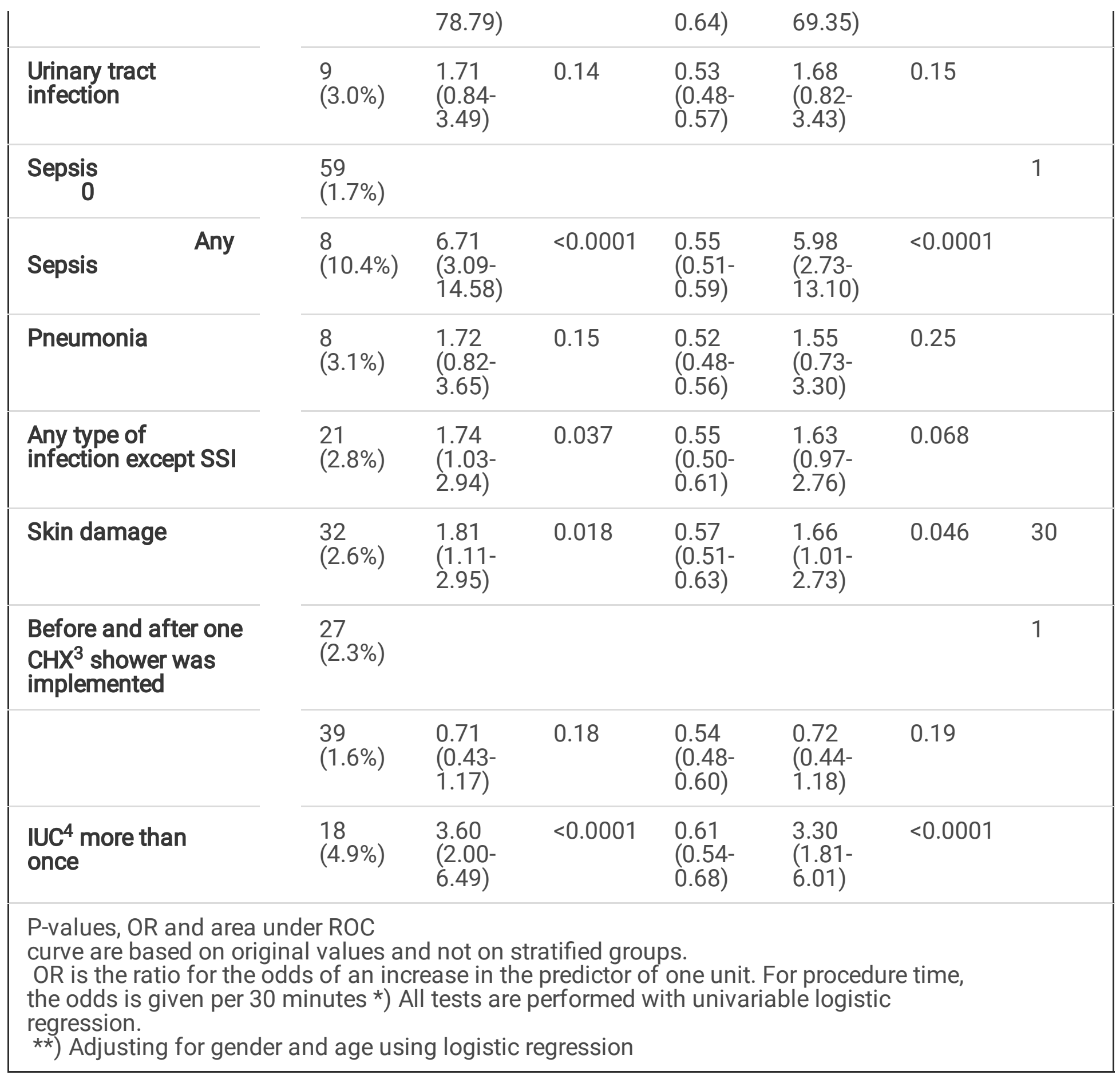

$\mathrm{m}^{1}=$ missing data

$2=$ pressure ulcers, Norton stage 1-4, recorder years $1-3$

$\mathrm{CXH}^{3}=$ chlorhexidine gluconate

${ }^{4}=$ in-dwelling catheterisation more than once during hospital stay

\section{Supplementary Files}


This is a list of supplementary files associated with this preprint. Click to download.

- STROBEchecklistcohort.docx 